\title{
ORCHESTRAL PRACTICE IN NIŠ AFTER THE SECOND WORLD WAR - FROM THE MUSIC DEPARTMENT OF THE NIŠ NATIONAL THEATER TO THE NIŠ SYMPHONY ORCHESTRA (1953-1965)
}

UDC 785.11"1953/1965" (497.11 Niš)

\section{Sonja Cvetković}

University of Niš, Faculty of Arts in Niš, Republic of Serbia

\begin{abstract}
The paper deals with the founding of a professional orchestral practice in Niš, and its beginnings that are related to the 1950s and 1960s. The research, conducted with the aim of considering the cultural and artistic contribution of the symphony orchestra, as an institution, to the dynamics of the musical life in Niš is based on local press insights and available archival material. Frequent changes in the organizational structure, financial and personnel problems, artistic rises and falls, polemical tones of the cultural public that followed the establishing of the orchestral practice in Niš after the Second World War testify to the dynamic atmosphere during the first decade of existence and artistic work of symphony orchestras that were predecessors of the Niš Symphony Orchestra, which until the mid-1960s was the only symphony orchestra ensemble in Serbia besides the Belgrade Philharmonic Orchestra.
\end{abstract}

Key words: Niš, concert orchestral practice, Music Department of the Niš National Theater, Niš Philharmonic Orchestra, City Symphony Orchestra

\section{INTRODUCTION}

Concert orchestral activity is a very important factor in the structure of the entire musical life of a community. Considering its continuity/discontinuity, professional engagement, and the institutional organization one can point not only to musical but also to many other aspects - ideological, cultural, economic - that have marked a certain historical period. Therefore, in this paper the music institutions in which the orchestral music practice existed in Niš is viewed in the context of an institutional theory of music, which interprets music institutions not only as a "liberal and democratic order/infrastructure of competent

Received January 11, 2020 / Accepted April 6, 2020

Corresponding author: Sonja Cvetković

University of Niš, Faculty of Arts

E-mail: cvetkos@mts.rs 
work, but also (as) a social mechanism for performing and developing practices within the struggle for influence and domination in reality, that is, struggles for musical, artistic, cultural, and social 'power'" (Šuvaković 2009, 16). Frequent changes in organizational structure, financial and personnel problems, artistic rises and falls, polemical tones in the cultural public that followed the establishing of the orchestral practice in Niš after the Second World War testify to the dynamic atmosphere during the first decade of existence and artistic work of the symphony orchestras that were predecessors to the Niš Symphony Orchestra, which until the mid-1960s was the only symphony orchestra ensemble in Serbia next to the Belgrade Philharmonic Orchestra.

The beginnings of orchestral practice in Niš after the Second World War are connected with the activities of amateur and semi-amateur ensembles of the City Civilian Orchestra (1946), the National Militia Brass Band (1950), the Radio Orchestra (1948) with the choir, folk, tamburitza and salon sections, which in 1952, thanks to the engagement of military musicians of the Niš Garrison, acquired the `physiognomy` of the symphony ensemble. In May 1952, this orchestra conducted by Stojan Andrić held the first symphony concert at the Niš National Theater, and in October performed at the Academy in honor of the Liberation Day of the city. ${ }^{1}$ In March next year, the orchestra now named the City Symphony Orchestra held a concert during which, in addition to works by Beethoven, Mozart and Haydn, premiered the Concerto for Violin, Piano and Orchestra by Petar Stojanović, with two soloists from Belgrade, Lazar and Milica Marjanović.

\section{ACTIVITIES OF THE SYMPHONY ORCHESTRA WITHIN THE MUSIC DEPARTMENT OF THE NIŠ NATIONAL THEATER}

When the radio orchestra was disbanded in 1953 due to the transition of a local radio station under the direction of Radio-Belgrade, the District People's Committee, as a body of national administration which implemented all ideological and legal directives of the state, inluding directions of development and the way of organizing artistic life, made the decision to establish the Music Department of the Niš National Theater. It consisted of a choir and an orchestra, whose activity was supposed to fill the emptiness in the musical life of Niš after the repeal of the radio orchestra.

Under the changed socio-political circumstances of the early 1950s, which in Yugoslavia led to the gradual relaxation of ideological pressure, increasing criticism of the dogmatic character of cultural life and the reduction of art to an exclusively propaganda function (Doknić 2013), there is also a growing awareness of the need to professionalize musical life within the structures of the local government in charge of culture. As there was no conductor with adequate professional education in the city, the director of the Niš National Theater, Isak Amar offered the position to Stevan Hristić, a prominent artist and leader of the republic and state professional associations, the president of the Composer's Association of Serbia and the Composer's Association of Yugoslavia. He was to help not only in the choice of the conductor of the Music Department of the Niš Theater, formally established in April 1953, but also as the

\footnotetext{
${ }^{1}$ At the progamme of the first concert were Beethoven's Coriolan Overture, Mendelssohn's Violin Concerto in E minor (soloist Ljudevit Pap, concertmaster of the Belgrade Philharmonic Orchestra), Schubert's Symphony No. 8 and Jakov Gotovac's Simfonijsko kolo, and on the second Mussorgsky's Night on the Bare Mountain, Fantasy from Puccini's opera Tosca and Liszt's Fantasy (Petković 1972, 31).
} 
personality who would organize the musical life in the city. Hristic proposed his former student Ilija Marinković, who at that time worked as a répétiteur at the Rijeka Opera. ${ }^{2}$

Under the directions of the versatile and highly educated Ilija Marinković, the orchestra and choir, apart from their primary task - performing music in dramatic plays on the theater stage $^{3}$ - also performed independently. They participated in the realization of the main cultural goals of an actual ideological discourse: musical enlightenment, cultivating an audience, and building a socialist society (Fig.1). The artistic highlight of Marinković's work as the conductor of the Music Department of the Niš National Theater was the concert and then stage performances of Verdi's operas Rigoleto (1955) and Traviata (1957) and concert performances of the opera Ero s onoga svijeta by Jakov Gotovac (1958), Cavalleria rusticana by Pietro Mascagni and Orfeo ed Euridice by Christoph Willibald Gluck (1959).

Another segment of the Music Department of the National Theater was the performance of orchestral and symphonic music for choir and orchestra. In addition to concerts of standard classical and early-romantic literature ${ }^{4}$ (Fig. 2, 3), the orchestra and choir also organized popular and promenade concerts for pupils, students and workers, often with introductory lectures by Marinković. They participated in humanitarian events, festive academies, state holiday celebrations and significant musical anniversaries such as the two concerts of 1956 dedicated to the $200^{\text {th }}$ anniversary of Mozart's birth and the $100^{\text {th }}$ anniversary of Stevan Stojanović Mokranjac's birth. Beside Marinković, conductors at the Music Sector of the National Theater were Stevan Guščin (choir conductor), Stojan Andrić (choir répétiteur), Vjekoslav Korže (assistant conductor and répétiteur) and Pavle Janković (second orchestra conductor since 1957).

Shortly after his arrival in Niš, Ilija Marinković noticed the main problems and obstacles confronting the professional functioning of the Music Department: lack of material resources, adequate concert and rehearsal hall ${ }^{5}$ and adequate staff, which were raised as crucial issues, given that the existing orchestra staff did not provide sufficient opportunities for the artistic development of the ensemble (A.[randjelović] M.[iodrag] 1953, 4). There were a small number of professionally educated musicians working for the orchestra. This resulted into the part-time hiring of musicians from the military orchestra, so that the

\footnotetext{
${ }^{2}$ Ilija Marinković (Budapest 1916 - Hamburg 2003), started his music studies in Belgrade, at the Music School "Stankovic", and continued at the Music Academy, where he graduated in 1942 composition in the class of Stevan Hristić and violin in the class of Petar Stojanović. He also studied medicine and specialized in phoniatrics, which made him interested in vocal studies. During the World War II he worked as a violinist in the Belgrade Philharmonic Orchestra and in the Opera Orchestra. After the war, he spent one year in the class of conductor Hans Swarowsky at the Vienna Academy of Music, played in the Wiener Symphoniker and conducted at the Wiener Kammeroper. In Belgrade, he also worked as a professor at the Music School "Mokranjac" and director of the Music School "Josif Marinković". During his studies at the Belgrade Music Academy, Marinković was three times awarded the "St. Sava" Prize for his compositions: Violin Sonata, String Quartet and Symphonic Poem Šuma na suncu (1939). Award for organizing and conducting activities received in 1959 by the Yugoslav Council of Education and Culture (Peričić 1969: 263-266; Peričić 1984, 571).

${ }_{3}^{3}$ Čučuk Stana, The Winter's Tale, A Midsummer Night's Dream, Othello, The Living Corpse... For some of these plays Ilija Marinković arranged and composed music (Petković 1972, 46).

${ }^{4}$ For example, Haydn's London symphonies, Mozart's Linz Sypmhony, Symphony No. 40 in G minor, Beethoven's First and Second symphonies, Schubert's Symphony No. 8 in B minor, Beethoven's overtures Egmont and Coriolan, Mendelssohn's Ruy Blas Overture, Schubert's Rosamunde Overture, Veber's Oberon Overture, Gluck's Iphigénie en Aulide Overture, Mozart's Clarinet Concerto in A major, Beethoven's Piano Concerto No. 5 in Es major (Petković 1972, 44).

${ }^{5}$ The rehearsals of the Music Department orchestra and choir were not held in the National Theater but in the inadequate rooms of the "Abrašević"Amateur Cultural Society and the classrooms of the Music School.
} 
balance between civilian and military musicians was 50:50. ${ }^{6}$ Marinković hoped that this problem would be adequately solved thanks to the staff educated by the Secondary Music School in Niš and the hiring of professional musicians from other cities (Ibid.).

However, the situation did not change much after three years: after numerous discussions at the sessions of the Council of Education and Culture of the District National Committee and the Theater Council, it was decided in 1956 to establish a orchestra of professional musicians at the Music Department of the National Theater instead of an orchestra of parttime hiring military musicians and amateurs: "which as such was cumbersome and immobile. A public call for a members of future professional orchestra has been announced, but it has not yet been possible to complete the orchestra" (J.[anković Dragoljub] 1956, 5).

Regardless of the above mentioned difficulties, the orchestra held 40 rehearsals at the beginning of its first concert season, from the second half of October until the end of 1953, and managed to perform twice to the Niš audience with the works of Gluck, Beethoven, Mozart, Gounod, Hristić and Konjović (A.[randjelović] M.[iodrag] 1953, 4). According to Marinković, in its future repertoire policy the orchestra will focus primarily on opuses of domestic composers ${ }^{7}$, while the existing repertoire whose framework consisted of standard European orchestra literature will be expanded by including works of Slavic composers: Tchaikovsky, Smetana and Dvořák (Ibid.). Exceptions from the conventional classicalromantic symphony repertoire represent the premieres of the Suite No. 1 for small orchestra by Igor Stravinsky, which the Niš audience "received beyond all expectation calmly and with tolerant patience, which gives an impetus to continue to cultivate this direction of musical styles in the Theater orchestra repertoire" (Lj.[ubiša Ružićc 1955, 5) and George Gershwin's Rhapsody in Blue, performed in 1958 with a soloist from Belgrade, pianist Nada Vujičić.

During the second concert season (1954/55) the orchestra of the Music Department held 10 premiere symphony concerts, and in the following years, with this ensemble performed as a soloists, renowned musicians from Serbia and other Yugoslav republics: Melita Lorković (piano), Fredi Došek (piano), Vera Veljkov (piano), Olga Mihajlović (piano), Andrija Preger (piano), Branko Pajević (violin), Lazar Marjanović (violin), Margaret NuriAndrć (violin), Jakov Srejović (flute), Bruno Brun (clarinet) as well as artists from abroad: Anton Soler, pianist of Slovenian origin from Argentina, and Karen Lund Christiansen, pianist from Denmark. It was also important for the professional development of the orchestra that they employed guest conductors: Djura Jakšić (Belgrade), Milivoj Ivanović (Titograd) and Todor Skalovski (Skopje).

Through a series of popular concerts for pupils, youth and workers ${ }^{8}$, the orchestra of the Music Department was able to reach a wide audience both in Niš and in guest performances in the nearby cities: Aleksinac, Soko Banja, Leskovac, Pirot, Bela Palanka. The organization of the subscription concerts also contributed to increasing the number of

\footnotetext{
${ }^{6}$ Although the plans of the Music Department scheduled the status of full-time employees for members of the orchestra and choir, it was never fully realized, so that the majority of the members were part-time employees, which certainly did not enabled professionalization of the Music Department. The number of members of the orchestra and choir varied from about 40 in each ensemble during 1954 and 1955 (Petković 1972, 36) to 21 orchestra musicians and 23 choir members in 1958 (J.[anković Dragoljub] 1958b, 5).

${ }^{7}$ Thanks to this repertoire orientation, the works of Stevan Hristić (Rhapsody for piano and orchestra, Poema zore, First Suite from the Ohridska legenda Ballet), Josif Marinković (Dositej Obradović Cantata), Svetomir Nastasijević (Omer and Merima Cantata), Petar Stojanović (Serenade for Strings and Flute) were premiered in Niš.

${ }^{8}$ Educational concerts included an introductory lecture followed by a adequate music programme, such as a thematic concert from the concert series for youth: Instrumental music of the $17^{\text {th }}$ century and the development of the concerto form held in 1957.
} 
visitors and the popularization of classical music (J.[anković Dragoljub] 1958c, 5). Five years later, in 1958 the orchestra and the choir of the Music Department of the Niš National Theater held their first successful performances abroad, in the Bulgarian cities Plovdiv and Haskovo ${ }^{9}$. Yet, there were no financial resources for the planned tours in Egypt and Greece. The concert season 1957/58 was rated as the most successful in the work of the Music Department that far: by mid-June 1958, the symphony orchestra had 40 performances attended by more than 15000 people and 9 opera performances, while 11 premiere symphony concerts were planned for the following season (J.[anković Dragoljub] 1958a, 5).

Despite the undoubted professional advancement and conquering more and more space in the cultural and musical life of the city, the Music Department did not have the full support of the administration of the Cultural Council of the Niš Municipality and the Drama Department of the National Theater whose managers insisted on its subordinate role in relation to Drama, especially as far as financial matters were concerned. From the very beginning of the establishment of the Music Department, the Niš Municipality had not been able to provide sufficient money for its proper functioning and fulfillment of the aims assigned to it. The excellent attendance at the opera performances caused suspicion among some city officials and among some members of the cultural life in terms of rejecting the alleged unrealistic idea of Ilija Marinković to establish the Opera as an independent sector of the Niš National Theater, while poor attendance at symphony concerts was criticized as a major problem. The intention of Ilija Marinković, which was obviously widely accepted, of gradually educating the audience and preparing them for the acceptance of symphonic music through opera, was not properly understood.

In this sense, it is indicative that the polemic in the local press Narodne novine (People's Press) and music journal Savremeni akordi (Contemporary Chords) initiated by the opinions expressed in the counseling about the musical life of Niš, held on June 30 1955. Besides the representatives of the political, cultural and musical life of the city, Dušan Plavša, music officer of the Council for Education and Culture of the Republic of Serbia and Ljubomir Kocić, secretary of the Serbian Society of Friends of Music also participated. In the introductory report entitled Musical development of Niš Ilija Marinković, in addition to listing the achieved results, also spoke about the uncertain future of the Music Sector of the National Theater due to the long-standing unresolved and accumulated problems and the lack of progress in providing elementary conditions for its work. "The most important is an increase in the number of managing and music staff, providing adequate rehearsal and concert hall, instruments and put a greater focus on professional rather than amateur work" (P.[opović Slobodan] 1955, 5). Marinkovic's justified pointing to the problems and the support he received from Dušan Plavša at the counseling were interpreted in the Narodne novine as advocating only for the greater financial support for the Music Sector, as dealing with economic, rather than professional musical issues, concluding that this discussion resembled to a "empty politicizing" (Ibid.). Dušan Plavša reacted to the writing of Narodne novine in the Savremeni akordi. He defended Ilija Marinković, noting that despite the "great progress in the cultural and musical development of Niš, there was still a misunderstanding for the needs of music and musicians by some local government representatives" (Plavša 1955, 78-80). Plavša

\footnotetext{
${ }^{9}$ At the concert programme dominated choral, instrumental and works for choir and orchestra by Yugoslav (Serbian, Croatian and Slovenian) authors: Stevan Hristić (Poema zore and Jesen), Bruno Bjelinski (Concertino for Piano, Strings and Percussion), Jakob Gallus (Ecce quomodo), Stevan Mokranjac (X Rukovet), Mihailo Vukdragović (Vezilja slobode).
} 
wonders how it was possible that the second largest city in Serbia, with a developed industry, cannot create decent material conditions for its cultural workers. As a concrete example, he states that because of unresolved housing problems, a number of musicians left Niš and went to other cities that offered them better conditions for life: "Can one blame people because they are not willing to live in a wagon at a train station, school classrooms or unhealthy rooms?" (Ibid.). An answer to Dušan Plavša's text, which was published in the next issue of Savremeni akordi, was sent by the Niš District Committee of the Yugoslav Alliance of Working People. In this response, Plavša's text is rated as "pamphletic" and his view of the musical life of Niš as "non objective and one-sided" (Bošković 1957, 28-30). The author of the response particularly resents at the fact that Plavša spoke critically about the Ivan Vučkovic's discussion at the counseling, noting that "Comrade Ivan Vučković is a member of the Secretariat of the Niš District of the Yugoslav Alliance of Working People and a prominent cultural and political worker of Niš" (Ibid.). In response, Dušan Plavša maintained his views, interrupting the discussion on the problems of the Music Department of the Niš National Theater and the musical life of Niš, because of the lack of arguments he sees no point for further polemic and especially because of understanding that "the last street in Niš should be paved and only then 'disbursed' for music culture", and especially "because of the mentality that favors folk music and football instead of the true values of the culture and art" (Plavša 1957, 31-32).

\section{REORGANIZATION OF THE MUSIC DEPARTMENT INTO THE NIŠ PHILHARMONIC ORCHESTRA}

By the February 20, 1959 decision of the National Committee of the Niš Municipality and with the consent of the Niš National Theater Council according to the previous report of the special Commission, the Music Department is separated from the National Theater and becomes an independent institution. The Commission found that both Drama and the Music Department have so far endeavored, as separate organizational sectors of the National Theater, to make a plan of their artistic programs without collision, but joint financial resources have led to "natural difficulties", especially in the implementation of the budget (Marinković 1959, 7). It had been suggested that in the future the Music Department changed its name to the Niš Philharmonic Orchestra and is self-financed from the municipal budget for culture.

A few months before its founding (March 7 1959), Ilija Marinković was optimistic towards the new music institution, and saw the separation of the Music Department from the National Theater, that is, its development into the Niš Philharmonic Orchestra as "a natural process of development of musical culture in this part of southeastern Serbia“" (Ibid.). Speaking about the tasks of the newly formed orchestra, he emphasized his responsible role in "social development in process of education and spreading music culture to the broader public, to citizens, workers and youth... In its activity, the Niš Philharmonic Orchestra would primarily performed symphonic music and operas and would also spread musical culture to the people through special popular concerts" (Ibid.) (Fig. 4, 5). Marinković announced further cooperation with the National Theater in the form of performance of stage-music works and continuous development of the operatic scene "because it has been proved that opera is the easiest way to reach the broad masses of listeners" (Ibid.). The Niš Philharmonic had an orchestra of 47, mostly professional 
musicians, as well as those employed by other music institutions in the city (Military Orchestra and Music School) and a choir of 44 members.

The Niš Philharmonic Orchestra continued the activity of the Music Department of the Niš National Theater in the programme realization of $1958 / 59$ by the concert performance of Gluck's opera Orfeo ed Euridice in March 1959, and at the end of the season, in June 1959, the Spring from the Haydn's Oratorio The Seasons and RimskyKorsakov's Scheherazade was premiered to the Niš audience.

However, at the beginning of 1960, there were a series of articles published in the local press that spoke in a critical tone about the artistic results and repertoire of the Niš Philharmonic Orchestra. "Contrary opinions have been heard lately about its purposefulness, whether the Niš Philharmonic Orchestra realized the needs of those it was intended for, whether within the funds it has (19 million dinars in the past and 25 million planned for this year) can do something more for affirmation and development of music art in Nišc (Lj.[ubisav] St.[anojević] 1960, 7). Although the author of this critique noted the effort to engage the more professional music staff in the Niš Philharmonic Orchestra, he still had the impression that not all the possibilities were fully exploited. "During the new season (from September last year), only one symphony concert was given and reprise performances of two operas: Traviata and Rigoleto. The participation of the Philharmonic Orchestra in events of occasional character (the Academy in honor of the Niš Liberation Day, the Yugoslav National Army Day, the anniversary of the "Stanko Paunovic" Factory) is somewhat more active" (Ibid.). Cooperation with primary schools was mentioned (15 educational concerts), but it was concluded that the Niš Philharmonic Orchestra failed to find its rightful place in the musical and cultural life of the city. "The evident aspiration for opera and the belief that the present Philharmonica is a springboard for this form should be reconsidered which, in our conditions still seems megalomaniac. On the other hand, the basic line and orientation of this institution, its role in spreading music culture among the wide masess of working people, is not quite clear. The Philharmonia would have to do more to seek a more modern repertoire, easier and more appropriate forms that, with more effort (and by far less resources), would accomplish a greater results“(Ibid).

Ilija Marinković reacted to this article in the next issue of Narodne novine. He pointed out to the danger that threatens not only the Niš Philharmonic Orchestra but also for the entire music culture from popular and newly-composed folk music, and contrary to the author of the critique who promoting the "easier" forms, insisted that the Niš Philharmonic Orchestra should not be "reduced to an institution for entertainment" (Marinković 1960, 8). In Marinkovic's opinion, the funds invested in Niš Philharmonic Orchestra were never enough, citing examples of philharmonic orchestras in Belgrade and Zagreb, whose budgets are twice the budget of the Niš Philharmonic Orchestra. Noting that the highest form of music is not opera but symphonic genre, but that the singing word on the stage is the most suitable form for spreading musical culture, Marinković thinks that the achieved results of the Niš Philharmonic Orchestra should be preserved and wonders "must one still fear the expression of megalomania that some individuals point out in public, light-headedly and irresponsibly?" (Ibid.).

The negative reviews were frequently repeated in the Narodne novine in the following months, apparently derogatory: "Did the Philharmonic Orchestra with its heterogeneous qualities and insufficient artistic level of the performed works justify its existence and importance that such institution must have in a city, musically undeveloped like Niš? The answer to this question was given by the audience, especially young people, who are less 
and less present in concert halls, thereby Philharmonic neglecting its educational role... Insufficient musical self-criticism and responsibility for musical art characterize the results of the Philharmonic so far. Modest possibilities and big, unrealistic and unfulfilled ambitions“" (Radojičić 1960, 7).

\section{INSTITUTIONALIZATION OF THE CITY SYMPHONY ORCHESTRA (1960)}

In April 1960, during the session of the Municipal Council for Education and Culture, the proposal of the Council of the Niš Philharmonic Orchestra on the reorganization of this institution was taken into account. The proposal stated that the Philharmonic Orchestra produced some results, but also showed a number of weaknesses in its organizational structure, repertoire and programme concept. A choir of 16 professional singers and only 4 soloists are not enough to develop the opera production more seriously (Anonym 1960a, 7). That is why the Council proposed the disbanding of the Philharmonic Orchestra and the establishment of the City Symphony Orchestra. The proposal still provided the existence of two performing ensembles: a symphony orchestra of 40 musicians and a choir that would have the same number of members. "This would create the conditions for more dynamic work adapted to the material possibilities, the interest of the audience and the cultural needs of the city" (Ibid.). In mid-July, during a session of the National Committee of the Niš Municipality, a decision in a form of a decree was made to establish a Niš Symphony Orchestra within Radio-Niš. The aim of the orchestra is to cultivate serious music through various events and concerts, and within its framework a small entertainment orchestra whose task is to perform popular entertainment music should be set up (Anonym 1960b, 7). Ilija Marinković disagreed with the decision to transfer the orchestra to the jurisdiction of RadioNiš, so after seven years of exceptional commitment to professionalize not only the orchestra but also the city's musical life, he resigned as conductor, although in the end, the City Symphony Orchestra never acted within the Niš radio station. As a conductor and director of the new orchestra they appointed Lambra Dimitrijević from Belgrade (Fig. 6, 7, 8).

The City Symphony Orchestra began its activity in October 1960 at the "Čair" Park by participating as a promenade orchestra in the event "Children's Week" (Petković 1972, 117) and then played "classical popular music on the podium of the 'Park' Hotel every day" (Petković 1993, 11). Although the first concert performance was announced for September, the first presentation of the City Symphony Orchestra to the concert audience took place in December. The small ensemble of the 25 members of the orchestra was completed with guests from Belgrade - students of the Music Academy who performed Stamic's Trio for Orchestra, Bach's Concerto for Two Violins and Orchestra, Schubert's Symphony No. 8 and Dvořák's Slavonic dance No. 8, with soloists Aleksandar Pavlović and Dragutin Bogosavljević. Violinist from Belgrade Lazar Marjanović, in the review of this concert, well-intentioned concluded that "in the near future, this young ensemble will be able to perform with success the compositions that represent significantly more level in terms of performance..." (Marjanović 1960, 7).

In June 1964, Lambra Dimitrijevic resigned as conductor in order to move to Belgrade. Since the orchestra could not find a permanent conductor, the conductor of the Belgrade Philharmonic Orchestra. Djura Jakšić was hired temporarily, and in the following year,

\footnotetext{
${ }^{10}$ The planned founding of the choir was never realized, so the City Symphony Orchestra has worked since its foundation exclusively as an instrumental ensemble.
} 
when the orchestra changed its name once again to the Niš Symphony Orchestra, conductor of the Belgrade Opera Borislav Pašćan was hired too. During the next years, the conductors of the Symphony Orchestra were Nikola Bojadžijev and Vančo Čavdarski, until the 1969/70 season, when with the arrival of Juraj Ferik in Niš, the orchestra succeeded in hiring a conductor who would be more permanently retained.

Therefore, the sixties in the history of the Niš Symphony Orchestra were spent in search of a permanent conductor, who would inevitably reflect on the artistic quality of the orchestra. This was also noticed by a critic of the journal Pro Musica who, while analyzing the musical life of Niš in the mid-1960s, expressed his opinion about the work of the City Symphony Orchestra: „The City Orchestra, which has existed for about fifteen years with minor pauses and various forms of work, though it does not yet have proper physiognomy, fulfills the musical life of Niš with more or less success" (Ivanović 1966, 9).

\section{CONCLUSION}

The beginnings of the orchestral practice in Niš, viewed through the work of the Music Department of the National Theater, the Niš Philharmonic Orchestra and the City Symphony Orchestra, testify to the numerous paradoxes and contradictions of local cultural and musical life. Controversies over the current problems of musical life in Niš and the role that the symphony orchestra should have in its development, often moved from the professional to the political sphere, affirming that in the field of art, aesthetic conflicts always have a political dimension, in the sense that they represent a euphemized form of struggle to impose a dominant principle of hierarchy within the field of cultural production but also a dominant vision of social reality (Bourdieu 1993,101-102).

Despite the fact that "...the cultural policy of socialist Serbia/Yugoslavia clearly demonstrated that professional art and high culture acted as an important factor of its policy and a natural indicator of the entire qualitative picture of its society" (Veselinović Hofman 2017, 21-22) and despite the official demands of the state cultural policy concerning the decentralization of culture and declarative support for the establishment of an institutional infrastructure in the field of music outside the main Yugoslav centers, in the case of Niš these demands achieved apparently quite slow and hectic results. Under the circumstances of insufficiently defined goals of local cultural policy which was balanced between professionalism and amateur, populist, and elitist, insufficiently defined financial, organizational and personnel criteria, symphonic music existed in the musical life of Niš mainly due to the enthusiasm of individuals who struggled to reach professional performing levels in an environment where it was first necessary to create and educate an audience to accept this musical genre. In this sense, the symphony orchestra of the Music Department of the Niš National Theater and the Niš Philharmonic Orchestra has undoubtedly played a key role in affirming the symphonic literature of both the Western European and Yugoslav musical canons.

Acknowledgement: The paper is the part of the project of Niš Branch of the Serbian Academy of Sciences and Arts (SASA): 0-10-17 "The Music Heritage of Southeast Serbia, Contemporary Creativity and the Formation of Taste". 


\section{REFERENCES}

Anonym., (1960a), "Predlog za reorganizaciju Niške filharmonije - hor i simfonijski orkestar grada?" ["Proposal for the reorganization of the Niš Philharmonic Orchestra - choir and symphony orchestra of the City?'], Narodne novine 16. april: 7.

Anonym, (1960b), "Osnovan Simfonijski orkestar grada Niša" ["The Niš Symphony Orchestra founded"], Narodne novine 18. jun: 7

A.[randjelović], M.[iodrag], (1953), "Put u kvalitet. Razgovor sa dr Ilijom Marinkovićem, rukovodiocem simfonijskog orkestra i hora pri Narodnom pozorištu" ["The way to quality. Interview with M. D. Ilija Marinkovic, leader of the Symphony orchestra and choir of the National Theater"], Narodne novine 5. decembar: 4.

Bošković, R., (1957), "Povodom napisa o jednom savetovanju muzičara niške oblasti” ["On the occasion of an article about a musicians conference from the Niš region"], Savremeni akordi, 1: 28-30 .

Bourdieu, P., (1993), The Field of Cultural Production: Essays on Art and Literature, Chicago University Press, Chicago.

Doknić, B., (2013), Kulturna politika Jugoslavije 1946-1963 [Cultural policy of Yugoslavia 1946-1963], Službeni glasnik, Beograd.

Ivanović, M., (1966), "Zatišje u muzičkom životu Niša“" ["A quietness in the musical life of Niš“"], Pro Musica, 13: 9 .

J.[anković, Dragoljub], (1956), "Bolji uslovi za razvoj muzičkog života u novoj sezoni“" [“A better conditions for the development of musical life in the new season"], Narodne novine 1. septembar: 5.

J.[anković, Dragoljub], (1958a), "Muzički život Niša. Najplodnija sezona“ ["The musical life of Niš. The best season"], Narodne novine 28. jun: 5.

J.[anković, Dragoljub], (1958b), "Sastavljen je repertoar Muzičke grane za ovu sezonu. Dalje širenje muzičke kulture" ["The repertoire of the Music Department for this season has been compiled. Further spread of music culture"], Narodne novine 1. novembar: 5.

J.[anković, Dragoljub], (1958c), "Koncerti u pretplati“" ["The concerts in subscription", Narodne novine 13. decembar: 5.

Lj.[ubisav], St.[anojević], (1960), "Neki problemi u radu Niške filharmonije" ["Some problems at the work of the Niš Philharmonic Orchestra"], Narodne novine 16. januar: 7.

Lj.[ubiša Ružić], (1955), "Iz koncertne dvorane. Gostovanje pijanistkinje Olge Mihajlović u Simfonijskom orkestru" ["From the concert hall. Guest performance of pianist Olga Mihajlović in the Symphony Orchestra"], Narodne novine 9. april: 5.

Marinković, I., (1959), "Pred osnivanje Niške filharmonije“" ["In front of the founding of the Nis Philharmonic Orchestra"], Narodne novine 1. januar: 7.

Marinković, I., (1960), "Povodom napisa 'Neki problemi u radu Niške filharmonije'" ["On the occasion of the article 'Some problems in the work of the Nis Philharmonic Orchestra'"], Narodne novine 23. januar: 8.

Marjanović, L., (1960), "Prvi koncert novog simfonijskog orkestra" ["The first concert of the new Symphony orchestra"], Narodne novine 17. decembar: 7.

Peričić, V. (1969), "Marinković dr Ilija“" ["Marinković M. D. Ilija“], u: Muzički stvaraoci u Srbiji, Prosveta, Beograd: 263-266.

Peričić, V., (1984), "Marinković, Ilija“ ["Marinković, Ilija“], u: Krešimir Kovačević (ur.), Leksikon jugoslavenske muzike I, JLZ "Miroslav Krleža“, Zagreb: 571.

Petković, S., (1972), Muzički život u Nišu i jugoistočnoj Srbiji 1877-1972 [The musical life in Niš and southeastern Serbia 1877-1972], rukopis, Muzikološki institut SANU, Beograd.

Petković, S., (1993), Četrdeset godina Niškog simfonijskog orkestra [Forty years of the Niš Symphony Orchestra], Narodne novine, Niški simfonijski orkestar, Niš.

Plavša, D., (1955), "Povodom jednog savetovanja muzičara niške oblasti“" ["On the occasion of a musicians conference of the Niš region"], Savremeni akordi, 4-5: 78-80.

Plavša, D., (1957), "Iza paravana (odgovor Dušana Plavše na članak Rad. Boškovića 'Povodom jednog savetovanja muzičara niške oblasti')“ "[Behind the paravane (Dušan Plavša's response to the Rad. Bošković article 'On the occasion of a musicians conference of the Niš region')"], Savremeni akordi, 1: 31-32.

P.[opović, Slobodan], (1955), "Održano savetovanje o muzičkom životu grada" ["A conference on the musical life of the city was held"], Narodne novine 2. jul: 5.

Radojičić, Lj., (1960), "Neki problemi muzičkog života u Nišu“ ["Some problems of the musical life in Niš"], Narodne novine 26. mart: 7. 
Šuvaković, M., (2009), "Institucionalna teorija muzike" ["An Institutional Theory of Music"], u: Vesna Mikić (ur.), Tematski potencijali leksikografskih jedinica o muzičkim institucijama, Fakultet muzičke umetnosti, Beograd: 9-16.

Veselinović Hofman, M., (2017), "What, How and Why in Serbian Music after the Second World War, in the Light of Ideological-Political Upheavals“, Muzikologija / Musicology, 23, vol. II: 15-29. https://doi.org/10.2298/MUZ1723015V

\section{POČECI ORKESTARSKE PRAKSE U NIŠU POSLE DRUGOG SVETSKOG RATA - OD MUZIČKE GRANE NARODNOG POZORIŠTA DO NIŠKOG SIMFONIJSKOG ORKESTRA (1953-1965)}

U radu se govori o utemeljenju profesionalne orkestarske prakse u Nišu, čiji su počeci vezani za pedesete $i$ šezdesete godine prošlog veka. Istraživanje sprovedeno sa namerom da se sagleda kulturni i umetnički doprinos institucije simfonijskog orkestra dinamici muzičkog života Niša, izvršeno je na osnovu uvida u napise iz lokalne štame i dostupni arhivski materijal. Česte promene u organizacionoj strukturi, finansijski i kadrovski problemi, umetnički usponi i padovi, polemički tonovi u kulturnoj javnosti koji su pratili utemeljenje orkestarske prakse u Nišu neposredno posle Drugog svetskog rata, svedoče o dinamičnoj atmosferi u okviru koje su protekle prve godine rada simfonijskih orkestara koji su prethodili osnivanju Niškog simfonijskog orkestra, do sredine 60-tih godina 20. veka jedinog simfonijskog orkestarskog sastava koji je pored Beogradske filharmonije delovao u Srbiji.

Ključne reči: Niš, koncertna orkestarska praksa, Muzička grana Narodnog pozorišta Niš, Niška filharmonija, Gradski simfonijski orkestar

\section{LIST OF ILLUSTRATIONS}

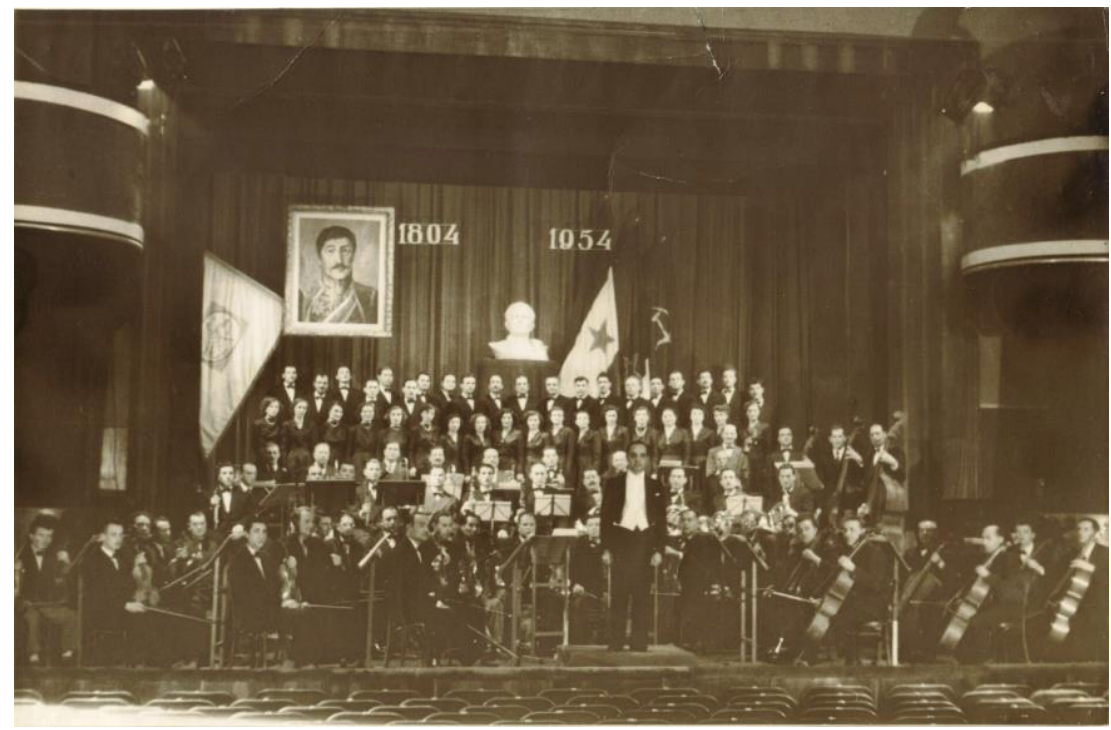

Fig. 1 Music Department (choir and orchestra) of the Niš National Theatre with conductor Ilija Marinković, 1954 

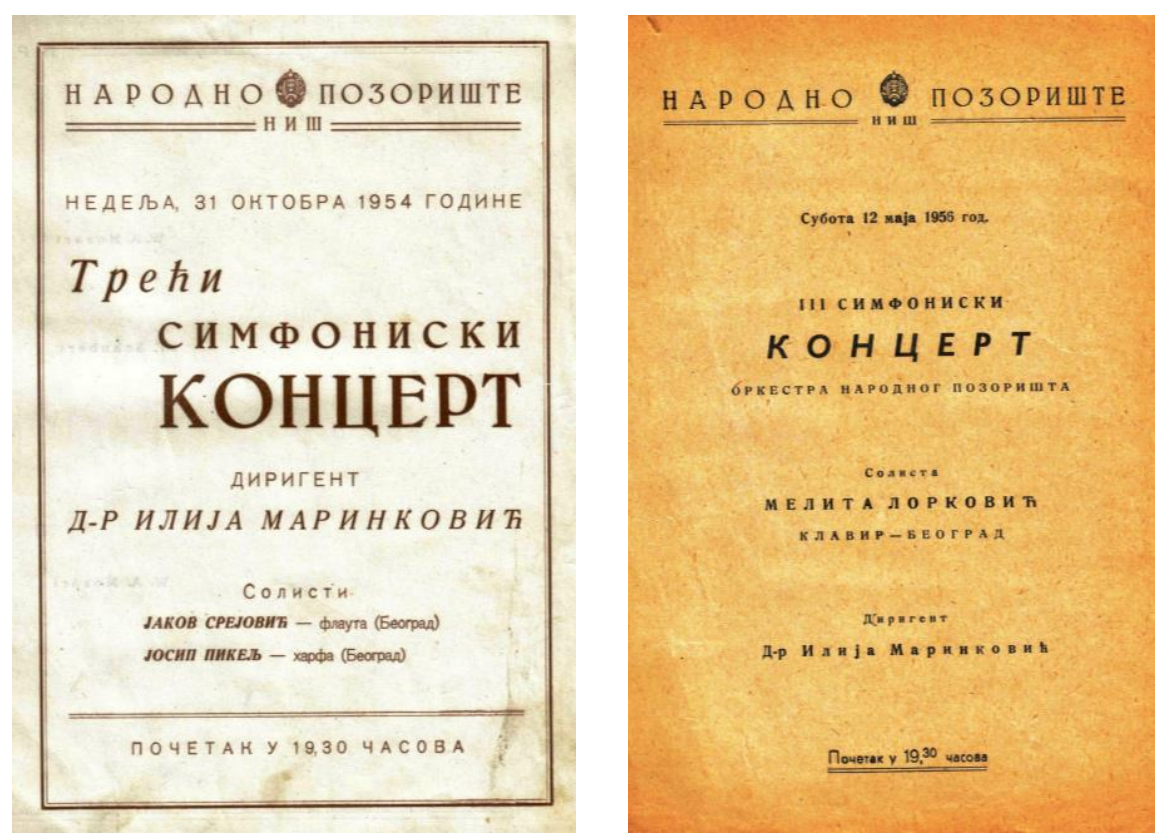

Fig. 2, 3 Concert programmes of the Music Department symphony orchestra, 1954, 1956
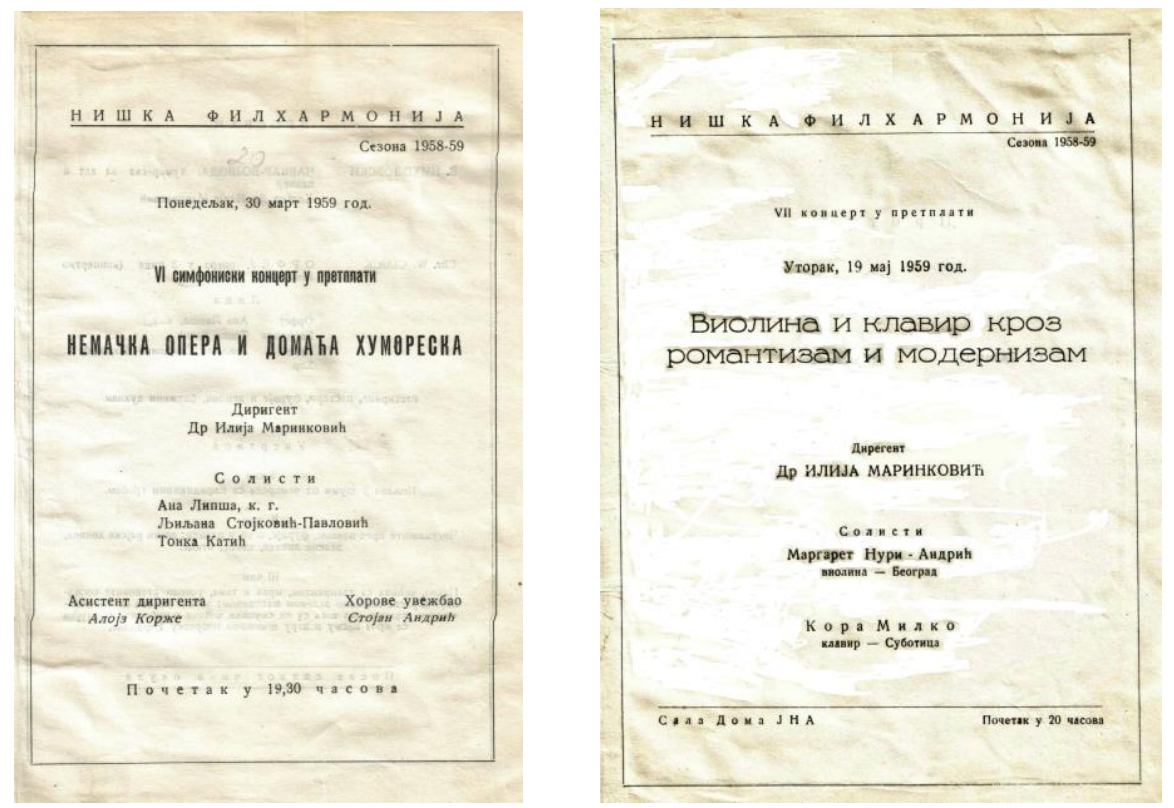

Fig. 4, 5 Concert programmes of the Niš Philharmonic Orchestra, 1959 


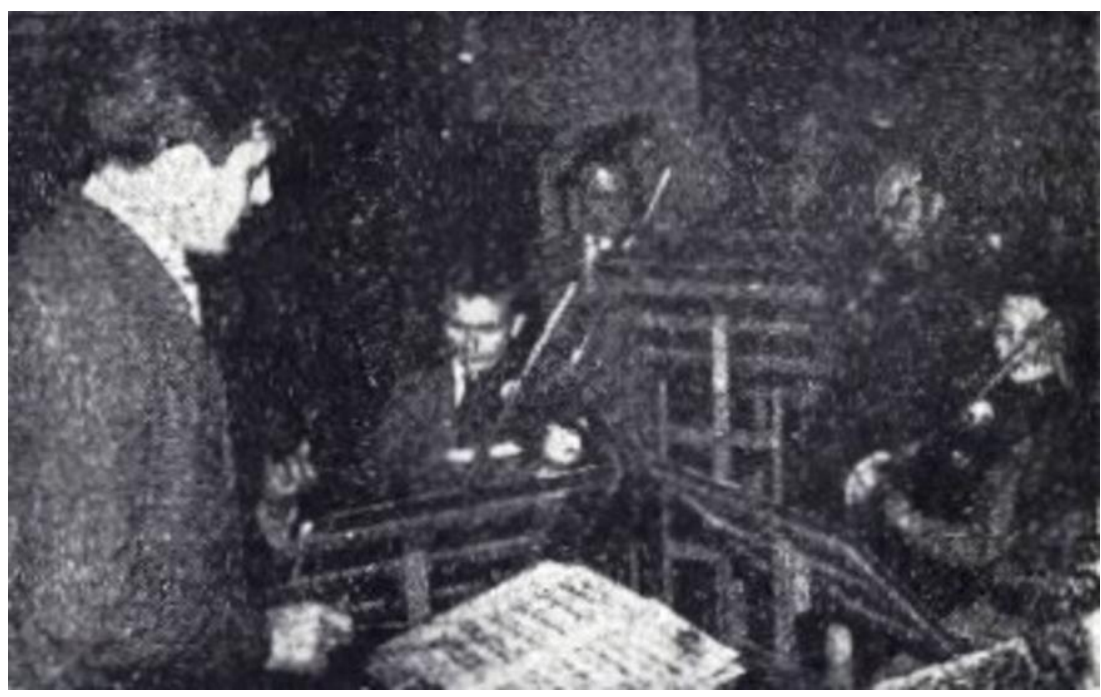

Fig. 6 Lambra Dimitrijević, conductor of the City Symphony Orchestra, 1960

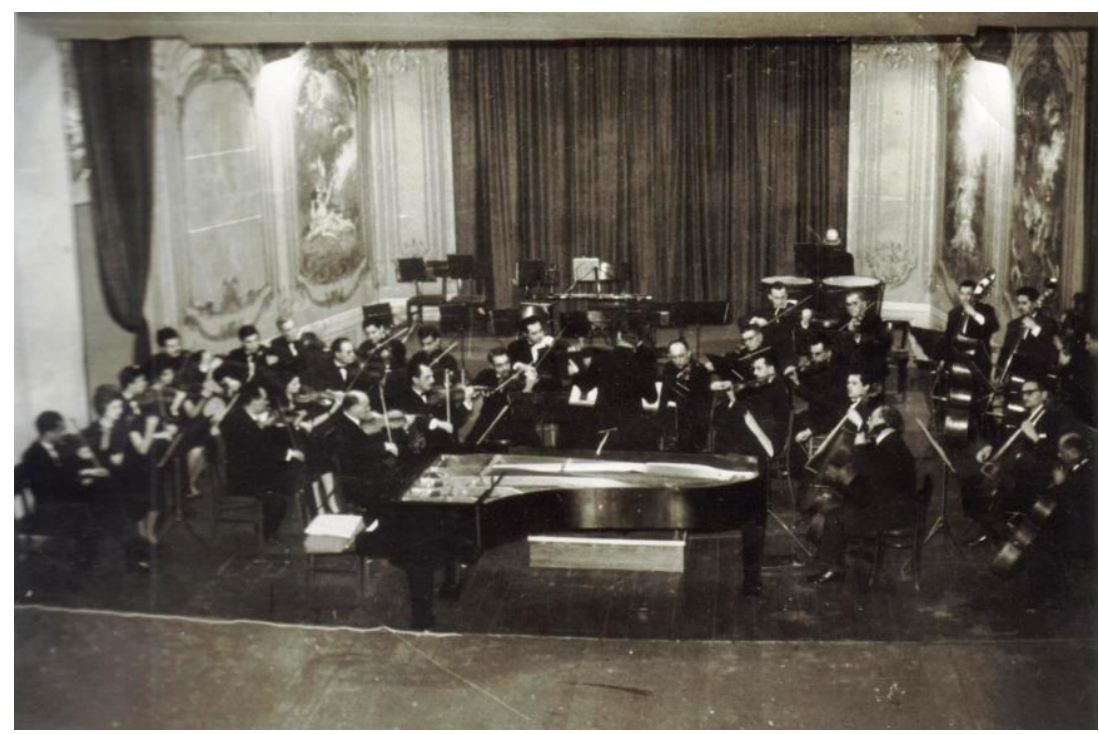

Fig. 7 The City Symphony Orchestra, 1962 


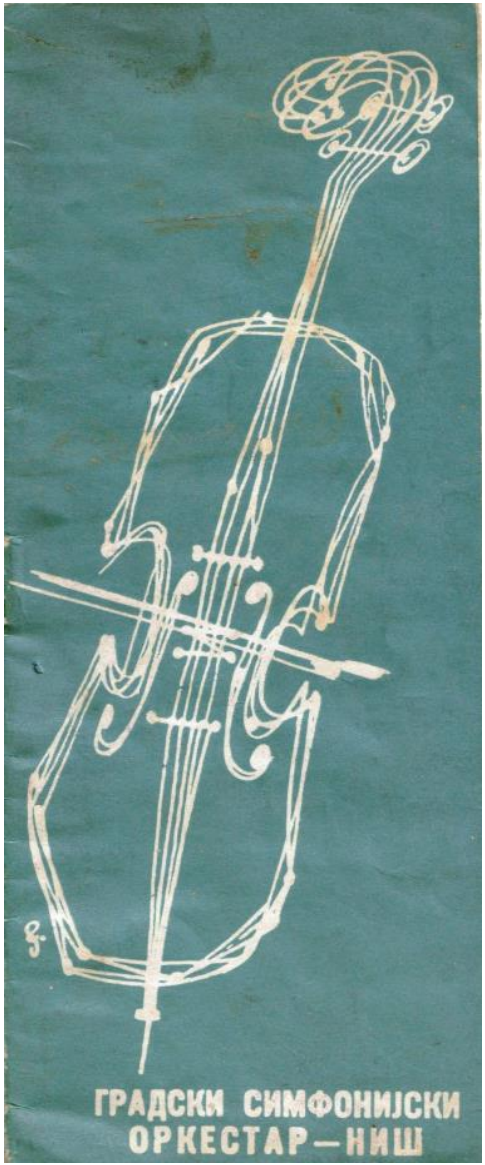

Fig. 8 Front page of the City Symphony Orchestra programme 